\title{
Simbolization of the Self \\ in Novgorod Monasticism Traditions: Archetypal and Social Aspects
}

\author{
Andrey G. Nekita and Segey A. Malenko* \\ Yaroslav-the-Wise Novgorod State University \\ 41 Bolshaya Sanktpeterburgskaya Str., \\ Veliky Novgorod, 173003, Russia
}

Received 24.12.2014, received in revised form 09.02.2015, accepted 28.04.2015

The paper analyses archetypal and socio-cultural foundations of Russian monasticism as a cultural phenomenon of the Novgorod land to determine its effect on the formation of the spiritual traditions of the Northwest region of Russia as a whole. The innovative trend in research is that the practice of monasticism, established in the Novgorod land, is studied by the methods of analytical psychology of C.G. Jung and that is the first time in Russian science.

Keywords: monasticism, monastery, archetype, symbol, icon, mark, the Self, Shadow, hagiography, authority, institutionalization, imagogenesis, imagostasis, amplification.

The study was funded by RHF as a scientific research project ("Monasticism: archetypal and social contexts of the Self symbolization (on the example of spiritual traditions of the territory of Novgorod)"), project № 14-13-53001.

Research area: philosophy.

Ever since the Middle Ages monks have taken a special place in the configuration of relationships between the prince, religious and veche (town's meeting in ancient Russia) power. A monk is an example of social repression, sacrificial service to God and the world, a mentor, a pastor and a confessor of sinful men, who seek for perfection unconsciously. Therefore, a Russian monk is a representation of the natural movement to the archetype of the Self. He is unconsciously perceived as someone, who has got the ideal meaning of life, approach to which is connected with the supernatural, and the archetype is his spiritual foundation. That is why in the climatic conditions of the North-West, the monasteries have been historically believed to be the examples of selfless changing the nature; they have showed the greatness of the human spirit in an effort to improve the earthly world. In this way, they have demonstrated to a man the path to the divine ideal via protecting people in continuous social conflicts and helping to survive in harsh nature conditions. The peculiarity of Russian holiness consists in the spiritual transformation of the monk when his life of service to God and monastery is aimed at the protection of the humanity and salvation

(C) Siberian Federal University. All rights reserved

* Corresponding author E-mail address: novsu@novsu.ru 
of mankind for a symbolic rapprochement of the Earth with the Heavenly World.

The interdisciplinary orientation of the research involves the penetration into cultural, social, philosophical and political-institutional aspects of the historical role of monasteries both in the Northwest region and in those regions of Russia, which have experienced the most significant effect of spiritual traditions of the Novgorod land.

The monastic way of Holiness as the social and cultural ideal of Novgorod land acts as a symbolic sublimation of monastic knowledge of the Self archetype, which organically combines individual and collective, human and divine.

\section{Introduction}

An unbiased, secular analysis of religious spiritual practices, that have developed the Russian statehood and culture for over a thousand years, makes it possible not only to identify the main directions of development of spirituality, but also to evaluate the potential of monasticism as a personal and collective creative practice of self-discovery. It should be recognized that due to the paradoxical combination of social services commissioning and the democratic competition of social institutions, the study of religion often turns either into plain-speaking apologetics of Christianity as a source of power and a powerful spiritual and managerial resource, or into a kind of atheistic criticism, and even into the formal chronological account of the Orthodoxy institutional history. However, the revival of Orthodoxy in Russia in the late $20^{\text {th }}$ - early $21^{\text {st }}$ century was feasible not only thanks the whim of the authorities or the church hierarchy, but, in particular, due to the presence of a powerful confessional rush of huge masses of people, having tired of alienated social experiments. It is no coincidence, for a long time priests have been often called not only the ministers of religion or confessors, but the "healers of human souls". This certainly makes them a sort of psychoanalysts who marked the $20^{\text {th }}$ century and discovered previously unknown aspects of the human soul for modern culture. Therefore, the establishment of such a relationship, revealing its deep, archetypal roots would lay the foundations of a productive social communication between the rapidly developing religious institutions and modern science as the leading productive force of our time. This dialogue will not only guide the individual's true spiritual development of the against the backdrop of ever-increasing media press, but also will allow harmonization of the cultural life in modern Russia on the example of monastic traditions, indicating as well to the authorities a balanced, tolerant scheme of social management in the difficult conditions of contemporary world. Having forgotten the past indiscriminate God-fighting experience, post-Soviet Russia continues to rely on depersonalized, alienated models of social communication and control, which creates a serious threat to national security and the successful transformation of the social and cultural life. In this sense, an appeal to the centuries-old practice of monasticism, which in many ways defined the country's status as the Holy Russia, will identify and fix the specific, individualized, mythological and symbolic (archetypal) methods of self-knowledge as a leading social, cultural, moral and ideological values that meet the most prominent humanist trends of. So the analysis of social, cultural and spiritual traditions of the Novgorod Republic, the specific ways of cooperation between the prince, and religious and veche authorities, which were conveyed by it within its political and territorial influence, must determine their scientific, social and cultural values in modern Russia. 


\section{Theoretical framework}

It should be stated that Russian monasticism has never observed in such a context before. Even Jungian studies of the Christian symbolism concerned only its general ideological and mythological bases. Undoubtedly, one should recognize that C.G. Jung, whose father was preparing him for the priesthood, interpreted the psychology of religion thoroughly and efficiently enough, was genuinely interested in various religious practices, laying so a base for his cultural "sofia". At the same time, the phenomenon of monasticism (monachism) did not get a proper coverage in his works, and his followers and disciples mainly went the other ways, distant from the religion, rather they got engaged in fruitful interpretation of archetypal symbolism in the context of childhood, gender problems, art, politics, etc. The exceptions in this case may be only M. Eliade and K. Kerenyi who ontologized Christian symbolism, interpreting it in the context of the evolution of world culture.

At the same time, even they have not been particularly interested in monasticism as a social, ideological, moral and spiritual practice. On the other hand, the analysis of the spiritual and moral foundations of the monastic life has a rich tradition in the Russian and world science. One should regard the complete dominance of sociological, psychological, religious, historical and factual, cultural and atheistic studies that focus attention on the specific problems of the functioning of the monastery in different situations of political and religious life.

\section{Statement of the problem}

The paper is devoted to the identification of a unique, symbolic model of perceiving the archetype of the Self, historically formed in monastic practices in the Novgorod land, and to evaluation of its impact on the formation of Russian spiritual traditions.

\section{Methods}

The most important theoretical and methodological basis of the paper is one of the great works of C.G. Jung, who "departed" from Freudian psychoanalysis and whose work not only accumulates the results of philosophical and psychiatric research, but also includes a wide range of original psychoanalytic interpretations of mythological, historical, ethnographic, philosophical, mystical and esoteric material. C.G. Jung called his method of cultural investigation a historical amplification, thus, bringing it out of the sphere of purely linguistic practices. It is a comparative analysis of the symbolic interpretations of cultural realities, that exist simultaneously in different areas of human existence, which reveals the balance of prevailing and repressed social and cultural meanings, while harmonizing a range of current and non-demanded, conscious and unconscious interpretations. As a result, C.G. Jung compiled the results of his theoretical generalizations in the fundamental psychoanalytic concept, which ontologized the role of the collective unconscious archetypes in the development of all forms of social interaction, which, nevertheless, is different from the traditional, as presented in classic rationalist and scientific tradition, interpretations of unconscious determinants of social life. At the same time, despite existing in the humanities skepticism about the Jungian ways of learning about the unconscious and the nature of their unconsciously determined social interaction, this paper makes a comprehensive attempt to revive Jungian findings, to apply and develop them.

Also among the most significant methodologies we should certainly mention the theoretical innovations in the field of research into the nature of unconscious preconditions for possible scenarios of social interaction, proposed within the framework of classical, Jungian, postclassical psychoanalysis and schizoanalysis. 
One study of particular note is the study of the American psychologist and analyst V. Odaynic, who most adequately applied Jungian approach for understanding the archetypal determination of social processes.

\section{Discussion}

Historically, the phenomenon of monasticism in Russia arose as a result of a particular configuration of social relationships and as a logical outcome of a difficult, protest-escapist displacement of pagan prototypes by emerging institutionalized religions, on the one hand, and as an effect of their sublimation by emerging secular power, on the other hand. This very conflict in explicit or, rather, in unconsciously rejected forms continues to exist until now, each time having been transformed, according to the spirit of the era and the unique pattern of the local traditions. Meanwhile, monasticism, forming a specific monastic way of life, is a prime example of the sublimation of the principles of religious knowledge of the Self archetype. Such sublimation "embodies quite rare in the modern world community of vital impulsion and existential human aspiration and allows you to create conscious understanding of the ancestral ways of social interaction of individuals as communitarian environment of their events. In addition, this sublimation presents the possibility of the development of this "fatal" for the modern social structure an abstract combination of knowledge, skills, experience, authority, competence and so on, which is considered to be the personality (Malenko. P. 62).

The biblical idea that "the kingdom of God is within you" (Gospel from Luke. P. 1015) makes it possible to establish the existential priorities in the search for meaning of life for the monks and their communities. Being of God, thus, acts as a symbolic reality of the monks' created and recognized internal "Self", which opens the supernatural and otherworldly space for the common man. So religious rituals, that make up the essence of monastic life, appear as everyday practices of self-knowledge, as a way to come closer to Perfection, which "does not belong to our world. It $i s$ something other than this world, or it comes to us from the other regions" (Eliade. P. 29). The rituals themselves "are attempts to eliminate the division between consciousness and unconsciousness, which is the real source of life, and provide people with an opportunity to create something like a reunion of the individual with the ancestors' homeland, reviving their instinctive nature" (Jung, 1995. P. 156). Reflected in Russian hagiographic literature and iconography, the rituals can analyze historical and inherited from generation to generation forming in the course of monastic everyday life mechanisms and scenarios of the Self archetype phenomenologization. That is why, not by chance, since their appearance in the ancient Russian society, the monks, free from the bustle and temptations, praying for deliverance from the pervasive sin of the world, induced the universal respect, reverence and worship.

Vows, prayer, labor and solitary life, all dedicated to God, have become at some point in history certain sacred social ideals, formed within the social organism, rather than prescribed or imposed by outside powers. Such religious dominance showed, on the one hand, the high moral and ethical priorities of ancient and medieval Russia and, on the other hand, Russians' everyday aspirations to come closer to God, freeing themselves from sin. Thus, the ancient Russian society in the practices of monasticism displayed unique and original understanding of the individual's role in the preservation and enhancement of God-created world. This understanding in the Middle Ages was sublimated as the Institute of Holiness. "The 'sanctity' of an idea or a thing means that they are endowed with the highest value in the face of what a man gets 
numb, so to speak. This holiness gives revelation; it is the power of illumination emanating from the archetypal figure. A man never feels as a subject in such a process, but always as an object only. Not a man perceives holiness, but it captures and fascinates a man; not a man knows its revelation, but it is revealed to a man instead; in addition, and a man cannot even boast that the opened truth is correctly understood. Everything seems to be going against a man's will: it is the contents of the unconscious, and science cannot state anything more for sure, as it cannot resort to faith, going beyond the specific scientific borders" (Jung. Psychology and alchemy, 1997. Pp. 51-52).

It is possible that the later paganism acted as the basis of this understanding of holiness, which, according to V.Toporov, "was interpreted as the result of special fruitful life force" (Toporov. P. 8). But soon afterwards the adoption of Christianity provoked the emergence of a new type of holiness - "spiritual one, understood as a kind of "super-human" state of grace when there is an increase in the spirit, creativity in the spirit" (Toporov. P. 9). In this type of holiness not only pagan and Christian elements are combined in a bizarre and non-contentious mode, but also the inner core of any faith remained unchanged as a recognition of the friendliness between divine, natural and social worlds, in which any active, moral and mature individual is able to make a contribution to the history of being.

Consequently, the Russian monasticism performs specific society forming practice, where it combines different cultural and spiritual traditions non-contentiously. The selfless service to God is also the service the world for which the monks pray and in their daily works struggle to atone for the world's sins, showing an example of creativity and dedication. Without any selfishness devoting themselves to faith, the monks appear as the individual's supreme ideal, which turns the routine of everyday worries into inspired acts for the sake of the people and God. "The monk goes away from the world and preaches abstinence, reserving their passions, and killing the body through a variety of hardships and self-torture. $<\ldots>$ The ugly side of the earth "dying" of the flesh $<\ldots>$ becomes a symbol of inner perfection" (Danilevskii. Pp. 256-257). "The Russian monks are pious people, $<_{\ldots}>>$ fish, jumping in the network of the Great Fisherman (Jung, Aion, 1997. P. 130). In this sense, they unconsciously feel the effect of the Self archetype of as a touch of the numinous, the divine, opening to them the glittering heavenly world.

This symbolic work with the Self archetype is a very dramatic, physically and emotionally strenuous activity, sometimes bordering with madness and obsession. Such conditions are described in detail in the psychoanalytic literature, and in particular in C.G. Jung's works, in his analysis of the spectrum of religious experience. One striking example of such research is the famous "Answer to Job" (Jung. Psychology and alchemy, 1997), a work dedicated to psychoanalytic consideration of the problem of personal relations and the divine in the Christian spiritual tradition. It is worth mentioning that continuing the tradition of Jung's study of these phenomena it is necessary to aim at the analysis of the dialectics of the earthly and heavenly, sinful and divine characteristic in both ancient and medieval Russia, and in the Russian Empire, as well.

Since these are the monastic practices which adequately assess the extent of their relationship in difficult socio-cultural contexts, the realization of the Self archetype is possible only with the removal of the destructive tendencies of the unconscious, presented in the collective image of a shadow. Therefore, the cognition of God by Russian monk should, inter alia, be considered as a practice of self-knowledge in the archetypical dialectics of the Self and the Shadow. "The 
Shadow, an unbreakable pair and the Self are mental factors, adequate understanding of which can be got only on the basis of the full and associated experience. These terms arise from the experienced reality and can be explained only through the further experience. $<\ldots>$ An unbreakable pair is immediately understood as a mental prototype of all the divine pairs. Finally, the Self, by virtue of its empirical characteristics, is perceived as eidos in the wake of the dominating ideas of unity and integrity, inseparable from all monotheistic and monistic systems" (Jung, Aion, 1997. Pp. 64-65).

It is in this regard, there appears the regional context, attracting the authors. The specifics of the relations of the prince, religious and veche authorities in Novgorod and its controlled lands allows discussing the unique configuration of the secular and the religious, pagan and Christian, individual and collective. This pattern was established in I.N. Danilevskii's works, who states: "Most likely, the prince led the army, was the high priest, which ensured his high position in society" (Danilevskii. P. 79). Accordingly, the real authority of religious leaders in Novgorod lands was to confirm the existence of (similar to the family one) the influence of priests on the minds of ordinary people. It was set by unconditional moral qualities of the clergy and religious people, while the dynamic unity of the social organization of Novgorod lands existed largely due to the indispensable and mighty personal component consistently represented in all social strata. At the same time, the history of everyday life does not offer any narrative of the ancient Novgorod people's approximation to the Self, with the exception of appearing in the Middle Ages hagiographic stories about the monks, who were later canonized. This very analysis of these sources may not only enable visualization of the daily practice of self-knowledge, which is typical of closed communities such as monasteries, but also put forward invaluable material for the disclosure of the nature and direction of the spiritual life of Novgorod as a whole.

At the same time, it should be said that selfhood practices, typical of Novgorod monasticism, despite the relative closeness and remoteness of the monastic spaces, do not develop in isolation from the rest of the world. Between them there is a process of continuous communication, in which there are two tendencies, in many ways representing the social significance of monasticism in Russia, as well as its epistemological and moral values. One of the areas is connected to the model of monastic life, deepening the knowledge of God and the purification of the world from sin, characteristic of the early centuries of Christianity in the ancient and medieval Russia, with decentralization as a specific attribute for this era of transition, fragmentation and parochialism. This shows the influence of the imagogenic trend of the archetype phenomenology, in which monasteries take into account local characteristics fully and comprehensively, allowing the monks to concentrate on the spiritual, selfless work and faith. Obviously, it was meant by outstanding Russian philosopher Ivan Ilyin, who told that "we are allowed to speak about faith only where the truth is perceived by the depth of our soul; where it is echoed in powerful and creative sources of our spirit; where the heart pronounces, and its voice is responds to by everything else in the man's essence" (Ilyin. P. 136).

On the other hand, with the increasing trend of confrontation, amid the growing centralization of power in Russia, we can see clearly a desire of the prince authorities to encroach on spiritual and geopolitical potential of monasteries, turning it into political capital and military reserve. This leads to the first attempts of submission of religious power to secular authorities, and escalating pressure on the Russian land from foreign 
enemies turns the monastic cloisters, on the one hand, into powerful, fortified fortress outposts on the borders of the princely estates, and, on the other hand, into centuries-old hostages of standoff between rival power groups and progressively more alienated from participation in public and political processes common people.

This situation seriously distorts the originally established monastic practice and results in a shift in the spiritual knowledge from the individual priority in the relationship between God, the world and a man to formal and depersonalized monks' intercession to God regarding the government and the world subordinate to it. "Institutional, primarily religiously formed faith, especially in the historically 'mature', civilized stages of mass society, was heading for "formalization", localization and implementation of the fatal "self-curtailing of the world" in the unconscious representations of the inhabitants about any arbitrarily chosen by them or their "pastors" object of faith for the purpose of its further absolute God status as the inevitable, finite, ontological "resort" (Nekita. P. 383). The only significant person of such a society is a political leader who, as if in concentrated form, is the exclusive sublimate of the Self archetype, whose symbolic content and personal availability from epoch to epoch becomes disproportionately smaller.

Moreover, such a sanctification of the politicians causes serious damage to moral authority of religious faith and the spiritual leaders, leaving ordinary people in a state of equidistant abandonment both from God and from Tsar as His vicar on earth. It was at this time when the value of self-knowledge in the bosom of religious faith was subject to serious doubt, erosion and degradation, which made monastic selfless service an exclusive spiritual product, becoming more and more faint on the background of the progressive increase of the vanity and formality in the religious world, while monasteries became only formal, semiotic outposts of imperial power, which started to subjugate the spiritual power. "Mastering" a religious form of faith, alienating the relevant content of the "Father" archetype, the tsar power at the same time assumes the status of the sacred authority of the underworld, creating the possibility of the total, forced "confession" of social individuals about the "loyalty" of the state ideology and legislation acts, brought up by their rational activity, mass sentiment and manufacturing functions. .

This "imagostasis" trend in the archetype phenomenology can be clearly traced in hagiographic literature that has actually been displaced and is in decline. It was only in the era of the hardest ordeals, when internal strife or foreign invaders threatened the very foundations of the state, when the archetypal and the highest spiritual authority of monasticism, having been hidden in the depths of the monastery cloisters, again started to inspire the laity and turned to be within the public interest by encouraging those in power, seeking for prayer and forgiveness, to sacrifice lands and huge valuable properties to monasteries

\section{Conclusion}

For the first time in Russian science there was made an attempt to analyze practices of monasticism, established in the Novgorod land, through the application of analytical psychology of C.G. Jung. It was his method of historical amplification, which allowed for the first time qualifying monasticism as a quintessence of spiritual traditions that are directly related to the development of religious and symbolic archetype of the Self, and harmonious combining individual and collective, everyday ways and regulatory approaches to the Absolute. In the specific conditions prevailing in the Middle Ages, under the configuration of the relationship between the 
prince, religious and veche power, a monk became a model of socially repressed, sacrificial service to God and the world, a mentor and spiritual guide for sinful men, unconsciously looking for absolute perfection. A Russian monk is an example of the natural ascension to the Self archetype, perceived by him as the ideal meaning of life, the approach to which had more to do with the otherworldly and the supernatural, while the archetype itself became a man's inner spiritual core. It is because even in difficult climatic conditions of NorthWest Russia, for centuries monasteries have been outposts and examples of selfless transformation of the natural environment, which demonstrates the greatness of the human spirit in an effort to improve the terrestrial world, and with this a man has been shown the way to the "heavenly" ideal, including a way of protecting people from the continuous series of social conflicts. Therefore Holiness has not been seen by monks as the utmost rise over the sinful world and its humiliation, for the triumph of the Divine idea of retribution, but rather as a transformation of people themselves, in which the active service of God and the monastic community is directed to the intercession and salvation of the human world in the name of the symbolic rapprochement of the Earthly world with the Heavenly one. As a consequence, Russian Holiness as the sacred embodiment of the Self archetype acts in a way of symbolic sublimation of corresponding monastic comprehension, which reunites individual and collective, human and divine in the most harmonious form.

\section{References}

1. Danilevskii, I.N. Drevniaia Rus' glazami sovremennikov i potomkov (IX-XII vv.) [Ancient Russia viewed by contemporaries and descendants (9-12 centuries)]. Moscow: Aspect Press, 1998, $399 \mathrm{p}$.

2. Eliade, M. Izbrannye sochineniia. Ocherki sravnitel'nogo religiovedeniia [Selected works. Essays on comparative religious studies]. Moscow: Ladomyr, 1999, 488 p.

3. Evangelie ot Luki [Gospel of Luke]. The Bible. The books of the Holy Scriptures and the New Testament. The Synodal translation, 2011. Pp. 994-1024.

4. Ilyin, I. Put' k ochevidnosti [Way to evidence]. Moscow, Republic, 1993, 571 p.

5. Jung, K.G. Aion. Moscow, Rephl-Book; Kiev: Vakler, 1997, 336 p.

6. Jung, K.G. Psikhologiia i alkhimiia [Psychology and alchemy]. Moscow: Rephl-Book; Kiev, Vakler, 1997, $592 \mathrm{p}$.

7. Jung, K.G. Sobranie sochinenii. Otvet Iovu [Collected works. The Answer to Job ]. Moscow: Canon, 1995, $352 \mathrm{p}$.

8. Malenko, S.A. Arkhetipicheskie stsenarii social'nogo vzaimodeistviia [Archetypal scenarios of social interaction]. Thesis of the Doctor of Philosophical Sciences. Veliky Novgorod, 2010, 451 p.

9. Nekita, A.G. Sotsializatsiia bessoznatel'nogo otchuzhdeniia v massovom obshchestve [Socialization of unconscious alienation in the mass society]. Thesis of the Doctor of Philosophical Sciences. Veliky Novgorod, 2010, 514 p.

10. Toporov, V.G Sviatost' $i$ sviatye v russkoi dukhovnoi kul'ture [The Holiness of the saints in the Russian spiritual culture]. Moscow, Gnosis - School of "languages of the Russian culture", 1995, Vol. 1.875 p. 


\title{
Символизация самости
}

\section{в традициях новгородского иночества: \\ архетипические и социальные аспекты}

\author{
А.Г. Некита, С.А. Маленко \\ Новгородский государственный университет \\ им. Ярослава Мудрого \\ Россия, 173003, Великий Новгород, \\ ул. Б. Санкт-Петербургская, 41
}

Статья посвящена исследованию архетипических и соииокультурных оснований русского иночества как культурного феномена Новгородской земли и определению его влияния на формирование духовных традиций Северо-Западного региона и России в иелом. Инновачионным трендом исследования является то, что практики иночества, сложившиеся в Новгородской земле, впервые в отечественной науке рассматриваются с применением методов аналитической психологии К.Г. Юнга.

Ключевые слова: иночество, монастырь, архетип, символ, образ, знак, самость, Тень, житие, власть, институализация, имагоген, имагостаз, амплификация.

Исследование финансировалось РГНФ в рамках научно-исследовательского проекта № 14-1353001 ("Иночество: архетипические и социальные аспекты символизации Самости в духовных традиииях Новгородской земли”).

Научная спещиальность: 09.00.00 - философские науки. 